\title{
Chinese Herbal Medicine for Myasthenia Gravis: A Systematic Review and Meta-Analysis
}

\author{
Shuang Chent, Meng-Bei Xut, Xiao-Li Zhou, Pei-Qing Rong, Ting-Yu Jin and \\ Guo-Qing Zheng*
}

Department of Neurology, The Second Affiliated Hospital and Yuying Children's Hospital of Wenzhou Medical University, Wenzhou, China

Myasthenia gravis (MG) is an acquired autoimmune disease with the disorder of the neuromuscular junction transmission caused by autoantibodies. Currently, various Chinese herbal medicines (CHMs) are widely used for MG. This meta-analysis was conducted to assess the effectiveness and safety of $\mathrm{CHMs}$ for $\mathrm{MG}$ and its possible mechanisms. Fourteen studies with 1039 individuals were identified by searching seven databases from inception to March 2017. The methodological quality was assessed by using 7-item criteria from the Cochrane's Collaboration tool, and which assessed $\geq 4$

Edited by:

Lingling Zhang,

Anhui Medical University, China

Reviewed by:

Claudio Ferrante

Università degli Studi G. d'Annunzio

Chieti e Pescara, Italy

Luigi Brunetti,

Università degli Studi G. d'Annunzio

Chieti e Pescara, Italy

*Correspondence:

Guo-Qing Zheng

gq_zheng@sohu.com

tThese authors have contributed equally to this work

Specialty section: This article was submitted to Inflammation Pharmacology,

a section of the journal

Frontiers in Pharmacology

Received: 18 June 2018 Accepted: 06 August 2018

Published: 30 August 2018

Citation:

Chen S, Xu M-B, Zhou X-L, Rong $P-Q$, Jin T-Y and Zheng G-Q (2018) Chinese Herbal Medicine for Myasthenia Gravis: A Systematic

Review and Meta-Analysis.

Front. Pharmacol. 9:969.

doi: 10.3389/fphar.2018.00969 "yes" in the domains were selected for detailed assessment and meta-analysis. All the data were analyzed using Rev-Man 5.3 software. Meta-analysis showed a significant effect of $\mathrm{CHM}$ as adjuvant therapy for improving the effectiveness compared with WCM alone or placebo in treating MG $(p<0.01)$. Moreover, there were fewer adverse effects and relapse rate in total when compared with the control group. The possible mechanisms of $\mathrm{CHM}$ for $\mathrm{MG}$ are associated with immunoregulation by reconstituting the functional ability of Tregs. In conclusion, despite the apparent positive results, the present evidence supports, to an extent, that CHM can be used for MG patients because of the methodological flaws and $\mathrm{CHM}$ heterogeneity. Further rigorous RCT for $M G$ is needed.

Keywords: myasthenia gravis, Chinese herbal medicine, systematic review, meta-analysis, T regulatory cells

\section{INTRODUCTION}

Myasthenia gravis (MG) is an acquired autoimmune disorder of neuromuscular junction characterized by the easy fatigability and weakness of the skeletal muscles in which autoantibodies mostly directed to the acetylcholine receptor (AChR) and muscle-specific kinase (MuSK) (Gilhus and Verschuuren, 2015; Sanders et al., 2016) In addition, about 10-15\% double-negative MG patients have antibodies against lipoprotein-related protein 4 (LRP4) (Li et al., 2018). The incidence rate of MG ranged from 0.3 to 3.0 per 100,000 worldwide (McGrogan et al., 2010). Epidemiological studies have shown an increasing incidence and prevalence of MG, especially among the elderly due to the diagnostic technique development (Zieda et al., 2018). Currently, the main treatments for MG include thymectomy, symptomatic and immunosuppressive (IS) treatments, and immunomodulating therapies such as intravenous immunoglobulin (IVIg) and plasma exchange (PLEX) (Sanders et al., 2016). However, there is no internationally accepted standard of care, and no one treatment best for all patients because of heterogeneous of MG 
(Sanders et al., 2016, 2018). In particular, orthodox therapy for effective symptom control often requires prolonged and even life-long IS treatment with debilitating adverse effects (Gotterer and Li, 2016). Furthermore, a proportion of refractory MG patients usually presented with the debilitating weakness, frequent relapses, MuSK or LRP4 antibody positive, postthymectomy, and/or required high-dose steroids and add-on other IS agents (Drachman et al., 2008; Suh et al., 2013). Thus, the alternative strategy for MG or declining the side-effect of IS is urgently needed.

Traditional Chinese medicine (TCM), one of the holistic medical systems in the world, has a history of thousands years and now still used actively in China and elsewhere worldwide. In modern time, Chinese herbal medicine (CHM), one of main treatment modalities of TCM, is widely used for MG in clinic and obtained experimental evidence (Orhan, 2013; Cui et al., 2015). However, the current evidence available is insufficient to support $\mathrm{CHM}$ as a routine use for $\mathrm{MG}$ due to the poor methodological quality of the primary studies (Lyu and Sun, 2015). Thus, we conducted a systematic review of CHM for MG focused on the clinical evidence and possible mechanisms according to the high-quality randomized-controlled clinical trials (RCTs).

\section{MATERIALS AND METHODS}

Ethical approval was not required for literature research. The design, implementation, and reporting of outcomes of this study were conducted according to the Preferred Reporting Items for systematic reviews and meta-analyses: The PRISMA Statement (Moher et al., 2009) and our previous articles (Yang et al., 2017).

\section{Database and Search Strategies}

Two reviewers independently searched the following databases: Chinese National Knowledge Infrastructure (CNKI), VIP Journals Database, Wanfang data Information Site, Chinese Biomedical Literature Database, PubMed, EMBASE, and Cochrane Library from inception to March 2017. The search strategy of PubMed was as follows, and was modified to suit other English or Chinese databases.

PubMed search strategy:

\#1. myasthenia gravis [mh]

\#2. Medicine, Chinese Traditional [mh]

\#3. Herbal Medicine [mh]

\#4. Integrative Medicine [mh]

\#5. traditional Chinese medicine [tiab]

\#6. herb* [tiab]

\#7. or/2-6

\#8. \#1 and \#7

\#9. randomized controlled trial [pt]

$\#$ 10. controlled clinical trial [pt]

\#11. randomized [tiab]

\#12. placebo [tiab]

\#13. drug therapy [sh]

\#14. randomly [tiab]

\#15. groups [tiab]
\#16. or/9-15

\#17. animals [mh] not (humans [mh] and animals [mh])

\#18. 16 not 17

\#19. \#8 and \#18

\section{Eligibility Criteria Types of Studies}

Only high-quality RCTs that received at least four out of seven "yes" in the domains through Cochrane risk of bias (RoB) tool were selected, regardless of its blinding, language, or publication status. Quasi-RCTs in which allocation to treatment was obtained by alternation, the use of alternate medical records, date of birth, or other predictable methods were excluded.

\section{Types of Participants}

We included participants with a diagnosis of MG, according to Myasthenia Gravis Foundation of America (MGFA) recommendations for Myasthenia gravis clinical trials (2000) (Jaretzki et al., 2000), MGFA recommendations for Myasthenia gravis clinical trials (2012) (Benatar et al., 2012), International Consensus Guidance for the Management of Myasthenia Gravis (2015) (Sanders et al., 2016), 5th National Conference of Neuroimmunology (NCNI) for the diagnostic criteria of Myasthenia gravis (China, 1997) (Xu, 2000) and Chinese Medical Association of Neurology (CMAN) Expert Consensus for the diagnosis and treatment of Myasthenia gravis (2011) (Chinese Medical Association of Neurology Branch of neuroimmunology Group, 2011). The other diagnostic criteria with comparable definitions were also used. The NCNI criteria were as follows: (1) in clinic, fluctuating skeletal muscle weakness that progressively worsens during periods of physical activity and improves after periods of rest. Typically, the weakness and fatigue are worse toward the end of the day; (2) in pharmacology, acetylcholinesterase inhibitors (CHEIs) are an effective treatment for MG; (3) in clinical electrophysiology, the low-frequency repetitive nerve stimulation (RNS) decreased more than $10 \%$, and single-fiber electromyography (SFEMC) reveals increased jitter; (4) in immunology, the positive AChR antibody contributes to diagnosis; (5) in pathology, if possible, it contributes to confirm the diagnosis, in which the post-synaptic muscle membrane is distorted and simplified, having lost its normal folded shape, and a decrease of concentration of AChRs on the muscle end-plate membrane (Xu, 2000). There were no restrictions on the gender, age, or race of patient. Patients belonged to allergy (allergic to more than two kinds of food or drugs), serious complications, such as cardiovascular diseases, renal insufficiency or other severe systemic diseases, and women in pregnant or lactating were not considered. Lambert-Eaton myasthenia syndrome was also excluded.

\section{Types of Interventions}

Analyzed treatments were CHM as monotherapy or adjuvant therapy in any dose or any forms. Comparator treatments were western conventional medication (WCM) or placebo. WCM refers to the combination of needed therapies of the following aspects (Skeie et al., 2010; Sanders et al., 2016): (1) general supportive care; (2) symptomatic therapies mainly 
with CHEIs such as pyridostigmine, edrophonium chloride, and neostigmine; (3) IS therapies such as glucocorticosteroids, azathioprine, Cyclosporin A (CYA), mycophenolate mofetil (MMF), Tacrolimus, methotrexate (MTX), cyclophosphamide, monoclonal antibodies, complement inhibition; (4) IVIg or PLEX; and (5) Thymectomy. Studies comparing one kind of CHM therapy with another CHM were excluded.

\section{Types of Outcome Measures}

The primary outcome measures included scales for assessing the extent of MG and muscle weakness using the Quantitative Myasthenia Gravis (QMG) scores (Barohn et al., 1998) and MG clinical absolute and relative scores (Wang et al., 1997). The MG clinical absolute and relative scores are a 60-point scale evaluate ptosis, eyelid fatigue, eye movement in the horizontal direction, right and left arm held outstretched at $90^{\circ}$, flexion of the knee and hip at $90^{\circ}$, facial muscles, chewing and swallowing, and respiratory muscle function (Wang et al., 1997). Each item is graded from 0 to 8 except facial muscles which score 0 to 4 . Lower scores represent the better function.

The secondary outcomes included: (1) relapse rate after follow-up; (2) total clinical effective rate; and (3) adverse events. The total clinical effectiveness rate $(\mathrm{Xu}, 2003)$ was assessed at the end of the treatment using five grades as clinical cure (the related clinical symptoms were recovered up to 95-100\%), markedly effective (the related clinical symptoms were recovered up to $80-95 \%$ ), effective (the related clinical symptoms were recovered at 50-80\%), improved (the related clinical symptoms were recovered at $25-50 \%$ ), and invalid (the related clinical symptoms were recovered $<25 \%$ ).

\section{Selection and Data Extraction}

Two reviewers independently identified the included studies and assessed the study eligibility. Reasons for the exclusion of studies were recorded. Information was extracted from the qualified articles by using a standardized data extraction form as follows: (1) general information: first author, the year of publication, and country; (2) characteristics of participants: sample size, age, gender, and disease duration; (3) methodological characteristics: study design, MG severity (Osserman classification), and diagnostic criteria; (4) details of intervention: type of intervention, duration of treatment, and follow-up time; and (5) outcome measures. Any disagreements were resolved by discussion with or by involving a third author.

\section{Assessment of Risk of Bias}

The RoB of included studies was assessed by the Cochrane RoB tool with seven domains as follows: (1) generation of random sequence; (2) allocation concealment; (3) blinding of participants and personnel; (4) blinding of outcome assessment; (5) incomplete outcome data; (6) selective reporting; and (7) other bias, including sample size estimate, comparable baseline characteristic, and potential interests. The RCTs which received at least four "yes" in the domains were selected.

\section{CHM Composition}

Specific herbs in the CHM formulae were recorded in Table 2. The frequency of use for a particular herb was calculated, and those used at a high frequency are described in detail.

\section{Description of Possible Mechanisms}

Animal-based mechanism studies of active compounds from frequently used herbs in MG and related autoimmune disease were searched. The following information was recorded for such studies: first author's name, publication year, the identity of active compounds and their herbal sources, experimental models used, intervention and control treatments, and suggested mechanisms.

\section{Statistical Analysis}

Statistical analysis was performed by Cochrane Collaboration Review Manager Software (RevMan 5.3). Standard chi-square test and $I^{2}$ statistic were used to examine the heterogeneity between trial and control results. A fixed effects model $\left(I^{2}<50 \%\right)$ or a random effects model $\left(I^{2}>50 \%\right)$ was used depending on the value of $I^{2}$. The value of $p<0.05$ was considered statistically significant. Dichotomous outcomes were calculated by the risk ratio (RR) with $95 \%$ confidence interval (CI), whereas continuous outcomes were summarized using standardized mean difference (SMD) with 95\% CI. Publication bias was checked graphically by using the funnel plot, and approximately symmetric shows no existence of publication bias.

\section{RESULTS}

\section{Study Selection}

A total of 2649 potentially relevant studies were identified in our search strategy from five databases, and 1201 duplicates were excluded. Of the rest 1448 articles, 1128 studies were removed by screening the titles and abstracts with the following reasons: (1) a case report or review, (2) not a clinical trial, (3) summary of clinical experiences, and (4) not Chinese herbal. By reading the remaining 320 full texts articles, we excluded 197 studies due to the following reasons: (1) not RCTs or not real RCTs, (2) combined with acupuncture, (3) not compared with WCM alone or placebo, and (4) retrospective study. Ultimately, 132 RCTs examining the efficacy of CHM for MG were included for qualitative analysis. Among them, 14 studies were assessed $\geq 4$ domains with "yes" and selected for further assessment and metaanalysis. On the contrary, other 118 studies were excluded as being assessed $\geq 3$ domains with "unclear" or "no." The screening process is shown in a flow diagram (Figure 1).

\section{Study Characteristics}

A total of 14 studies were finally included, published from 2003 to 2016. Only one study was published in English, and the rest of 13 studies were published in Chinese including eight master/doctorial theses. The sample sizes of the included studies ranged from 30 to 241 , with a total of 1039 subjects, 521 patients in treatment groups, and 518 patients serving as controls. Among the 14 studies, no trial compared the CHM with placebo, and 


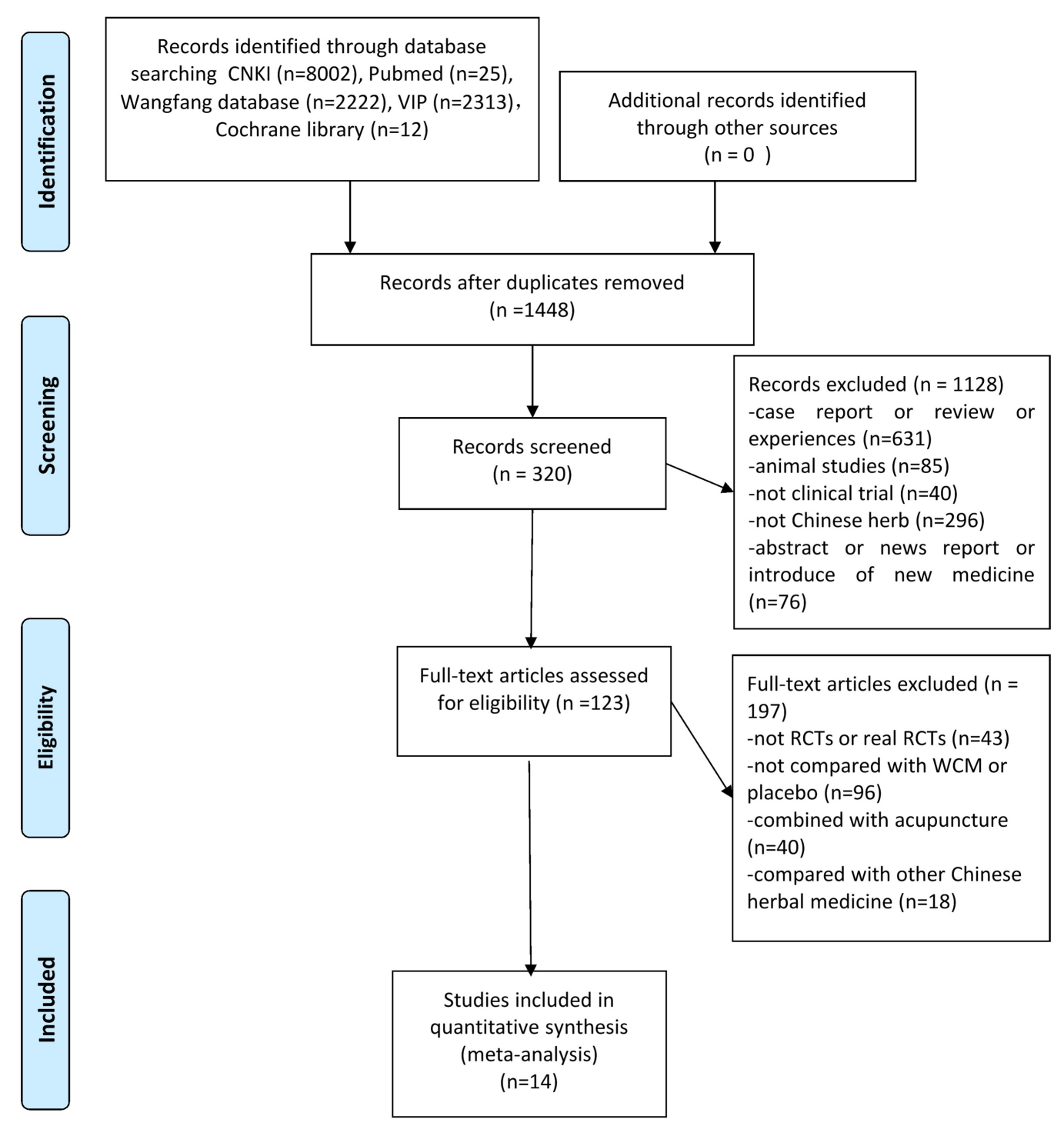

From: Moher D, Liberati A, Tetzlaff J, Altman DG, The PRISMA Group (2009). Preferred Reporting /tems for Systematic Reviews and MetaAnalyses: The PRISMA Statement. PLoS Med 6(7): e1000097. doi:10.1371/journal.pmed1000097

For more information, visit www.prisma-statement.org.

FIGURE 1 | Flowchart of study screening.

the comparisons of $\mathrm{CHM}$ alone with pyridostigmine bromide or corticosteroids were performed in three studies. CHM plus pyridostigmine bromide and corticosteroids vs. pyridostigmine bromide and corticosteroids were conducted in four studies, CHM plus pyridostigmine bromides. Pyridostigmine bromide in five studies, CHM plus corticosteroids vs. corticosteroids in two studies. The course of treatments lasted from 2 to 9 months. Adverse effects were reported in 10 studies, among which 2 studies reported no adverse events occurred. The characteristics of the 14 included studies were described in detail in Table 1. The constituent of CHM in each included study was listed in detail in Table 2.

\section{Risk of Bias and Quality of Studies}

The RoB was assessed by using the Cochrane RoB tool. Among the 14 included studies, the number of criteria varied from $4 / 7$ to $7 / 7$. All of the included studies were reported random allocation, majority studies (12/14) had described the concrete method of random sequences generation, while the remaining 2 studies had no details. Two studies mentioned the concealment allocation. 


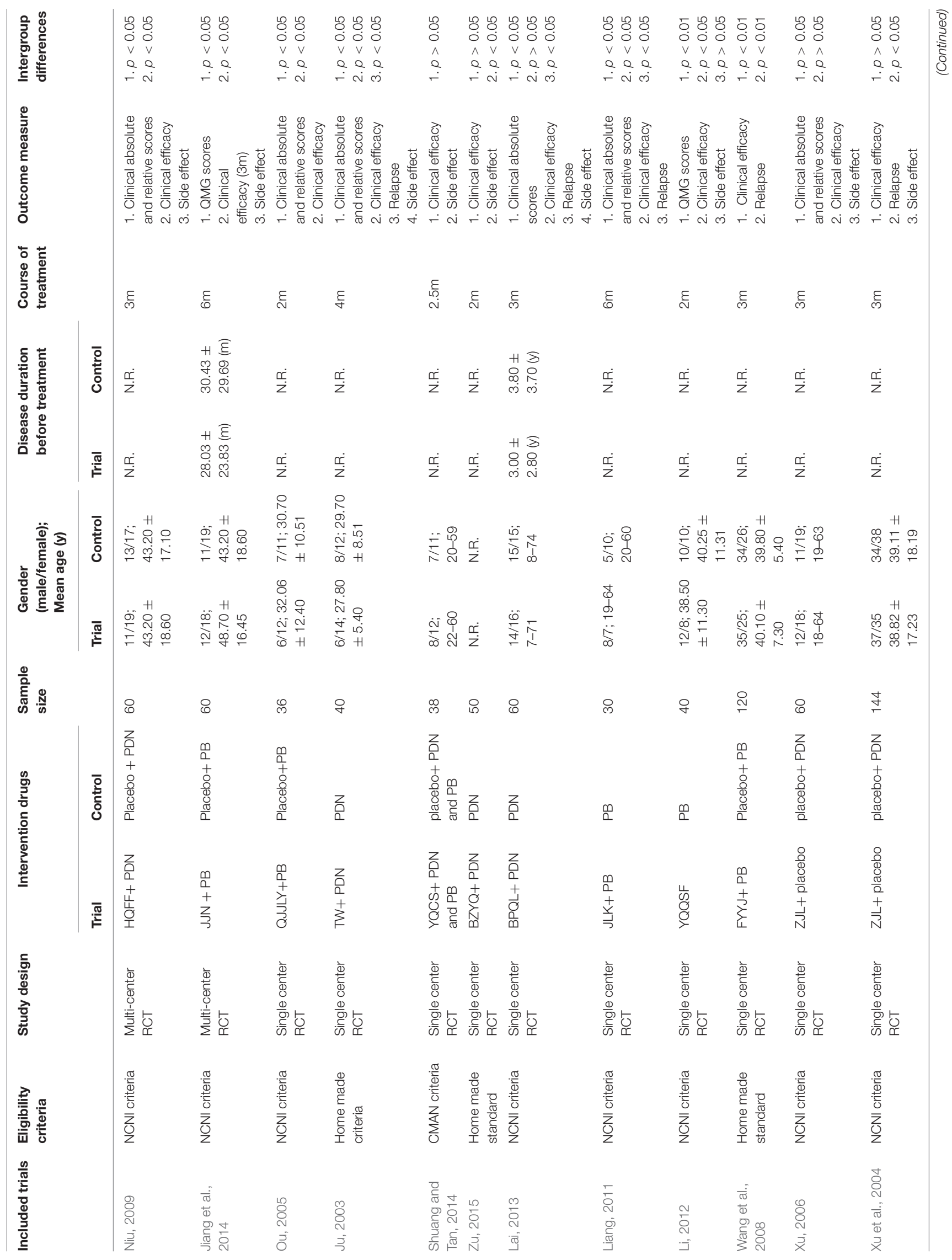




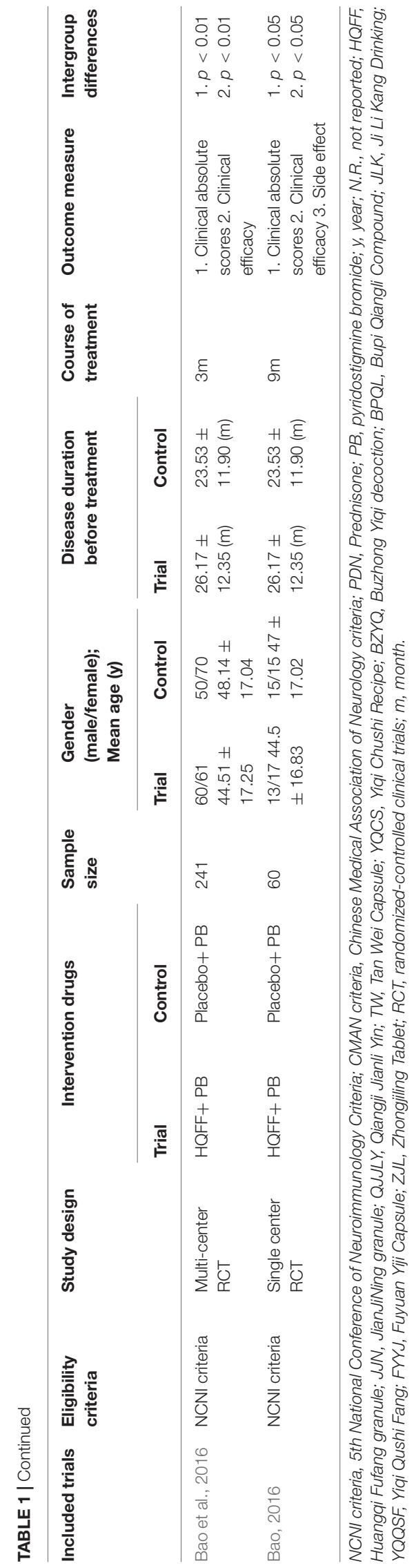

Eight studies reported the blinding, including three double-blind and five single-blind; the remaining studies neither mentioned the blinding nor provided any other information to assess the blinding (unclear). All studies met the criterion of incomplete outcome data as drop-out data or no drop-out patients were reported specifically. Moreover, baseline comparisons were well performed, while none had sample size estimate. More details about RoB assessment of each trial were presented in Table 3.

\section{Effectiveness $\mathrm{CHM}$ vs. Placebo}

None of RCTs used a specific comparison between CHM and placebo.

\section{CHM vs. WCM}

Three studies (Xu et al., 2004; Xu, 2006; Li, 2012) compared CHM with WCM. One study (Li, 2012) showed that CHM was superior to pyridostigmine bromide according to QMG scores. The other two studies ( $\mathrm{Xu}$ et al., 2004; Xu, 2006) showed no significant difference between CHM and corticosteroids according to MG clinical absolute and relative scores. Meta-analysis of three studies (Xu et al., 2004; Xu, 2006; Li, 2012) showed no significant difference in total clinical effective rate $(n=244, \mathrm{RR} 0.99,95 \%$ CI: $0.93-1.05, p=0.75$; heterogeneity $\chi^{2}=1.58, d f=2, p=0.45$, $I^{2}=0 \%$, Figure 2$)$ and recovery rate $(n=244$, RR $1.17,95 \% \mathrm{CI}$ : $0.61-2.23, p=0.64$; heterogeneity $\chi^{2}=2.21, d f=2, p=0.33$, $I^{2}=10 \%$, Figure 3 ) comparing CHM with pyridostigmine bromide or corticosteroids.

\section{CHM Plus WCM vs. WCM}

Eleven studies were included. One study (Jiang et al., 2014) showed that Jianjining Granule paratherapy significantly improved QMG score at both 3 and 6 months compared to pyridostigmine bromide $(p<0.05)$. Meta-analysis of three studies (Ou, 2005; Niu, 2009; Lai, 2013) showed that CHMs paratherapy were significant for decreasing MG clinical absolute and relative score $(n=156, \mathrm{MD}-2.36,95 \% \mathrm{CI}:-3.10$ to $-1.61, p<0.00001$; heterogeneity $\chi^{2}=1.53, d f=2, p=0.47$, $I^{2}=0 \%$, Figure 4) compared to pyridostigmine bromide and corticosteroids; one (Ju, 2003) study also have positive result compared with corticosteroids $(p<0.01)$; three studies (Barohn et al., 1998; Bao, 2016; Bao et al., 2016) failed to pool analysis because of high heterogeneity and all showed statistical significant difference compared with pyridostigmine bromide $(p<0.01)$. Meta-analysis of four studies (Ou, 2005; Niu, 2009; Lai, 2013; Shuang and Tan, 2014) showed CHMs paratherapy significantly improved the total clinical effective rate $(n=194, \mathrm{RR}$ 1.05, 95\% CI: 0.99-1.12, $p=0.11$; heterogeneity $\chi^{2}=0.79, d f=3$, $p=0.85, I^{2}=0 \%$, Figure 5) compared with pyridostigmine bromide and corticosteroids; two studies (Ju, 2003; Zu, 2015) are similar result $(n=90, \mathrm{RR} 1.06,95 \% \mathrm{CI}: 0.94-1.20, p=0.34$; heterogeneity $\left.\chi^{2}=0.16, d f=1, p=0.69, I^{2}=0 \%\right)$ compared with corticosteroids; five studies (Wang et al., 2008; Liang, 2011; Jiang et al., 2014; Bao, 2016; Bao et al., 2016) failed to pool analysis because of high heterogeneity and all showed statistical significant difference compared with pyridostigmine bromide $(p<0.01)$. Meta-analysis of five studies (Ju, 2003; Xu et al., 2004; 
TABLE 2 | Ingredients and usage of CHM.

\begin{tabular}{|c|c|c|c|c|}
\hline $\begin{array}{l}\text { Included } \\
\text { studies }\end{array}$ & $\begin{array}{l}\text { Prescription } \\
\text { name }\end{array}$ & Ingredients of herb prescription & $\begin{array}{l}\text { Usage of } \\
\text { prescription }\end{array}$ & Preparations \\
\hline Niu, 2009 & HQFF & $\begin{array}{l}\text { Radix Astragali seu Hedysari } 50 \mathrm{~g} \text {, Radix Pseudostellariae } 25 \mathrm{~g} \text {, Rhizoma Atractylodis } \\
\text { Macrocephalae } 15 \mathrm{~g} \text {, Rhizoma Cimicifugae } 10 \mathrm{~g} \text {, Radix Saposhnikoviae } 10 \mathrm{~g} \text {, Radix } \\
\text { Angelicae Sinensis } 10 \mathrm{~g} \text {, Fructus Lycii } 15 \mathrm{~g} \text {, Fructus Corni } 15 \mathrm{~g}\end{array}$ & $300 \mathrm{~g}$ tid po & Granule \\
\hline Jiang et al., 2014 & JJN & $\begin{array}{l}\text { Radix Astragali seu Hedysari, Radix Pseudostellariae, Rhizoma Atractylodis Macrocephalae, } \\
\text { Fructus Aurantii, Rhizoma Cimicifugae, Herba Leonuri, Radix Saposhnikoviae, Radix } \\
\text { Angelicae Sinensis, Fructus Lycii, Radix Polygoni Multiflori, Fructus Corni }\end{array}$ & $210 \mathrm{~g}$ bid po & Granule \\
\hline Ou, 2005 & QJJLY & $\begin{array}{l}\text { Radix Astragali seu Hedysari, Radix Codonopsis, Rhizoma Atractylodis Macrocephalae, } \\
\text { Radix Angelicae Sinensis, Rhizoma Cimicifugae, Radix Bupleuri, Pericarpium Citri, Radix } \\
\text { Glycyrrhizae, Cayratia japonica }\end{array}$ & $20 \mathrm{ml}$ tid po & Oral liquid \\
\hline Ju, 2003 & TW & Radix Astragali seu Hedysari, Placenta Hominis, Semen Strychni, Radix Glycyrrhizae & 2\# tid po & Capsule \\
\hline Shuang and Tan, 2014 & YQCS & $\begin{array}{l}\text { Radix Astragali seu Hedysari } 30 \mathrm{~g} \text {, Rhizoma Atractylodis } 15 \mathrm{~g} \text {, Rhizoma Atractylodis } 15 \mathrm{~g} \text {, } \\
\text { Semen Coicis } 30 \mathrm{~g} \text {, Rhizoma Atractylodis } 15 \mathrm{~g} \text {, Radix Achyranthis Bidentatae } 10 \mathrm{~g} \text {, Semen } \\
\text { Arecae } 10 \mathrm{~g} \text {, Fructus Chaenomelis } 15 \mathrm{~g} \text {, Radix Angelicae } 15 \mathrm{~g} \text {, Radix Salviae Miltiorrhizae } \\
15 \mathrm{~g} \text {, Poria } 15 \mathrm{~g} \text {, Radix Bupleuri } 10 \mathrm{~g} \text {, Radix Glycyrrhizae } 10 \mathrm{~g}\end{array}$ & $205 \mathrm{~g}$ qd po & Granule \\
\hline Zu, 2015 & $B Z Y Q$ & $\begin{array}{l}\text { Pericarpium Citri } 15 \mathrm{~g} \text {, Radix Angelicae Sinensis } 10 \mathrm{~g} \text {, Radix Codonopsis } 30 \mathrm{~g} \text {, Radix } \\
\text { Glycyrrhizae } 5 \mathrm{~g} \text {, Rhizoma Cimicifugae } 10 \mathrm{~g} \text {, Rhizoma Atractylodis } 15 \mathrm{~g} \text {, Radix Astragali seu } \\
\text { Hedysari } 60 \mathrm{~g} \text {, Radix Bupleuri } 10 \mathrm{~g}\end{array}$ & $250 \mathrm{ml}$ bid po & Decoction \\
\hline Lai, 2013 & BPQL & $\begin{array}{l}\text { Radix Astragali seu Hedysari } 60 \mathrm{~g} \text {, Radix Codonopsis } 20 \mathrm{~g} \text {, Rhizoma Atractylodis } \\
\text { Macrocephalae } 15 \mathrm{~g} \text {, Radix Angelicae Sinensis } 12 \mathrm{~g} \text {, Herba Epimedii } 15 \mathrm{~g} \text {, Radix Aconiti } \\
\text { Lateralis Preparata } 40 \mathrm{~g} \text {, Rhizoma Smilacis Glabrae } 20 \mathrm{~g}\end{array}$ & 200/3 ml tid po & Decoction \\
\hline Liang, 2011 & JLK & $\begin{array}{l}\text { Radix Astragali seu Hedysari, Radix Codonopsis, Rhizoma Atractylodis Macrocephalae, } \\
\text { Semen Coicis, Radix Angelicae Sinensis, Rhizoma Cimicifugae, Radix Bupleuri, Cayratia } \\
\text { japonica, Radix Polygoni Multiflori Preparata }\end{array}$ & $200 \mathrm{ml}$ bid po & Oral liquid \\
\hline Li, 2012 & YQQSF & $\begin{array}{l}\text { Radix Astragali seu Hedysari } 60 \mathrm{~g} \text {, Radix Ginseng } 15 \mathrm{~g} \text {, Rhizoma Atractylodis } \\
\text { Macrocephalae } 15 \mathrm{~g} \text {, Radix Angelicae Sinensis } 15 \mathrm{~g} \text {, Rhizoma Atractylodis } 12 \mathrm{~g} \text {, Rhizoma } \\
\text { Alismatis } 12 \mathrm{~g} \text {, Rhizoma Cimicifugae } 9 \mathrm{~g} \text {, Cortex Phellodendri } 9 \mathrm{~g}\end{array}$ & $200 \mathrm{ml}$ bid po & Decoction \\
\hline Wang et al., 2008 & FYYJ & $\begin{array}{l}\text { Radix Ginseng, Cornu Cervi Pantotrichum, Rhizoma Atractylodis Macrocephalae, Poria, } \\
\text { Radix Rehmanniae Preparata, Radix Bupleuri, Rhizoma Ligustici Chuanxiong, Rhizoma } \\
\text { Acori Tatarinowii, Radix Gentianae, Radix Glycyrrhizae }\end{array}$ & 8\# tid po & Capsule \\
\hline Xu, 2006 & ZJL & $\begin{array}{l}\text { Cornu Cervi Pantotrichum, Radix Ginseng, Semen Cuscutae, Radix Astragali seu Hedysari, } \\
\text { Fructus Lycii, Radix Angelicae Sinensis, Herba Ephedrae, Herba Epimedii, Placenta } \\
\text { Hominis, Rhizoma Atractylodis, Poria }\end{array}$ & 4\# tid po & Tablet \\
\hline Xu et al., 2004 & ZJL & $\begin{array}{l}\text { Cornu Cervi Pantotrichum, Radix Ginseng, Semen Cuscutae, Radix Astragali seu Hedysari, } \\
\text { Fructus Lycii, Radix Angelicae Sinensis, Herba Ephedrae, Herba Epimedii, Placenta } \\
\text { Hominis, Rhizoma Atractylodis, Poria }\end{array}$ & 4\# tid po & Tablet \\
\hline Bao et al., 2016 & HQFF & $\begin{array}{l}\text { Radix Astragali seu Hedysari, Rhizoma Cimicifugae, Radix Saposhnikoviae, Rhizoma } \\
\text { Atractylodis Macrocephalae, Radix Bupleuri, Radix Angelicae Sinensis, Fructus Lycii }\end{array}$ & $10 \mathrm{~g}$ tid po & Granule \\
\hline Bao, 2016 & HQFF & $\begin{array}{l}\text { Radix Astragali seu Hedysari, Rhizoma Cimicifugae, Radix Saposhnikoviae, Rhizoma } \\
\text { Atractylodis Macrocephalae, Radix Bupleuri, Radix Angelicae Sinensis, Fructus Lycii }\end{array}$ & $10 \mathrm{~g}$ tid po & Granule \\
\hline
\end{tabular}

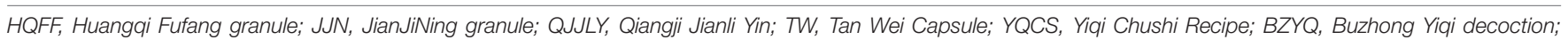

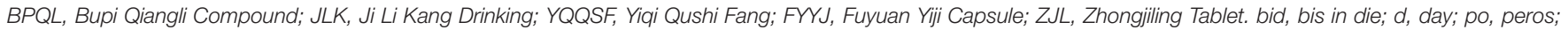
qd, quaquedie; tid, ter in die; \#, tablet.

Wang et al., 2008; Liang, 2011; Lai, 2013) showed that CHMs paratherapy were significant for improving the relapse rate after follow-up ( $n=291$, OR 0.22, 95\% CI: 0.11-0.48, $p=0.0001$; heterogeneity $\chi^{2}=0.77, d f=4, p=0.94, I^{2}=0 \%$, Figure 6) compared WCM controls.

\section{Adverse Event}

Adverse effects were reported in 10 studies, and the remaining four (Ou, 2005; Wang et al., 2008; Liang, 2011; Bao et al., 2016) studies did not mention. Two (Niu, 2009; Jiang et al., 2014) studies reported that no adverse events occurred during treatment. Eight (Ju, 2003; Xu et al., 2004; Xu, 2006; Li, 2012; Lai, 2013; Shuang and Tan, 2014; Zu, 2015; Bao, 2016) studies reported detailed information of adverse effects with
4/247 patients in trial group vs. 51/245 patients in control group. The frequently occurring adverse events are liver function abnormalities, high fasting glucose, hormonal obesity, infection, gastrointestinal discomfort, granulocytopenia, insomnia, skin allergy, thrombocytopenia, and femoral head necrosis. In particular, 0/247 patients suffered hormonal obesity in the trial groups and $21 / 245$ patients did so in control groups. The majority of adverse effects were mild, and serious adverse events such as life-threatening were not found in included studies.

\section{Description of the CHMs}

A total of 11 herbal decoctions were used in 14 included studies. The number of herbal components in the formulae varied from 4 to 13 . The most frequently used herbs across 
TABLE 3 | The Cochrane Collaboration's tool for assessing RoB.

\begin{tabular}{lllllllll}
\hline & A & B & C & D & E & F & G & H \\
\hline Niu, 2009 & + & + & + & + & + & + & + & $7+$ \\
Jiang et al., 2014 & + & + & $?$ & $?$ & + & - & + & $4+$ \\
Ou, 2005 & + & $?$ & + & + & + & $?$ & + & $5+$ \\
Ju, 2003 & + & $?$ & - & - & + & + & + & $4+$ \\
Shuang and Tan, 2014 & + & $?$ & + & + & + & + & + & $6+$ \\
Zu, 2015 & + & $?$ & - & - & + & + & + & $4+$ \\
Lai, 2013 & + & $?$ & - & - & + & + & + & $4+$ \\
Liang, 2011 & + & $?$ & - & - & + & + & + & $4+$ \\
Li, 2012 & + & $?$ & - & - & + & + & + & $4+$ \\
Wang et al., 2008 & $?$ & $?$ & + & - & + & + & + & $4+$ \\
Xu, 2006 & + & - & + & + & + & + & + & $6+$ \\
Xu et al., 2004 & $?$ & $?$ & + & $?$ & + & + & + & $4+$ \\
Bao et al., 2016 & + & $?$ & + & - & + & $?$ & + & $4+$ \\
Bao, 2016 & + & $?$ & + & - & + & + & + & $5+$ \\
\hline
\end{tabular}

$A$, adequate sequence generation; $B$, concealment of allocation; $C$, blinding of participants and personnel; $D$, blinding of outcome assessment; $E$, incomplete out-come data; F, selective reporting; $G$, other bias.

all formulae were listed as follows: milkvetch root (Radix Astragaliseu Hedysari/Astragalus membranaceus), largehead atractylodes rhizome (Rhizoma Atractylodis Macrocephalae), Chinese angelica (Radix Angelicae Sinensis), largetrifoliolious bugbane rhizome (Rhizoma Cimicifugae), Chinese thorowax root (Radix Bupleuri), liquorice root (Radix Glycyrrhizae), tangshen (Radix Codonopsis), barbary wolfberry fruit (Fructus Lycii), Indian bread (Poria), divaricate saposhnikovia root (Radix Saposhnikoviae), ginseng (Radix Ginseng) (Table 4).

\section{Possible Mechanisms}

The pharmacological effects of active compounds of frequently used herbs on MG and related autoimmune disease are as follows: (1) Astragalus membranaceus: promoting the expression of transcription factor Forkhead box protein P3 (FoxP3) to up-regulate $\mathrm{T}$ regulatory cells (Tregs) (Qu et al., 2010;
Jin et al., 2013), and decreasing cytokine expression such as IL4 and IL-13 (Chen et al., 2014b; Zhao et al., 2016); (2) Radix Ginseng: increasing number of Tregs and inhibiting Th17 cell differentiation (Bae et al., 2012; Chen et al., 2014a; Jhun et al., 2014; Lee et al., 2015; Chen et al., 2016); (3) Bupleurum polysaccharides (BPs) from Radix Bupleuri: a decrease of autoantibodies and immunoglobulin G (IgG) (Wang et al., 2009; Table 5). (4) Huperzine A (HupA), isolated from Huperzia serrata and flavonoid derivatives from Buzhongyiqi Decoction exhibited anti-acetylcholinesterase effects (Orhan, 2013; Cui et al., 2015).

\section{DISCUSSION}

\section{Summary of Evidence}

Fourteen high-quality RCTs with 1039 individuals were identified for analysis. The findings demonstrated that CHM as adjuvant therapy for MG could reduce the QMG scores or MG clinical absolute and relative scores, reduce relapse rate, and improve total clinical effective rate. There were fewer adverse effects in comparison with controls. The possible mechanisms are associated with immunoregulation by reconstituting of the functional ability of Tregs. Thus, the present evidence supports, at least to an extent, that $\mathrm{CHM}$ can be recommended for routine use for MG patients.

\section{Limitations}

Although the high-quality RCTs were included, there were still some methodological weaknesses in the primary studies. First, only two studies reported the allocation concealment. A trial with inadequate or unclear concealment of allocation is likely to overestimate the therapeutic effect (Higgins and Green, 2011). Second, blinding was available to reduce the occurrence of performance bias and ascertainment bias in clinical trials (Lewis, 2003). Eight studies used the blinding, whereas only four studies used double-dummy, placebo design. Placebo plays a crucial role

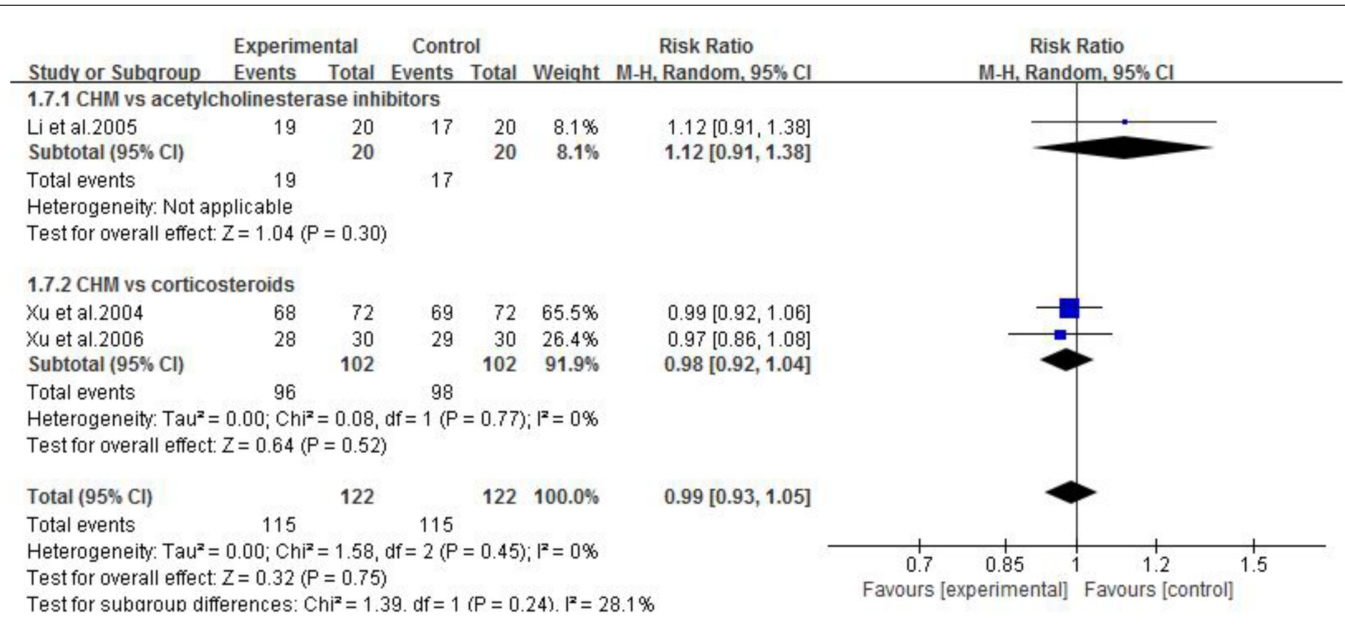

FIGURE 2 | The forest plot: The total clinical effective rate of CHM vs. WCM. 

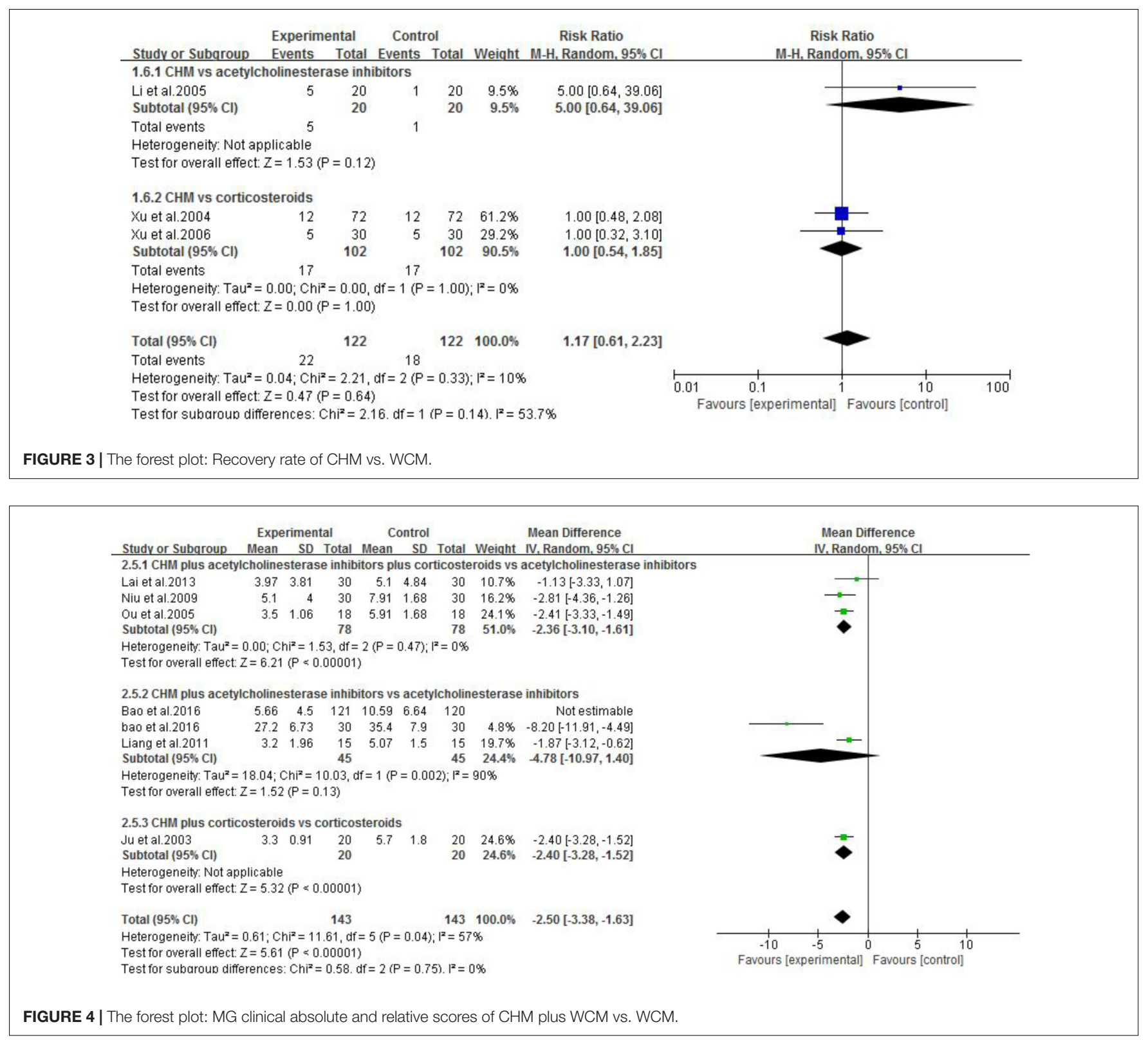

as a control in RCTs. A placebo effect is conceptually defined as the beneficial effect associated with an intervention that does not include the presumed active ingredients. Thus, placebocontrolled randomized trials are well-recognized method when evaluating the efficacy of clinical treatment. In the present study, none of RCTs used a direct comparison between CHM and placebo, while several RCTs adopted double-dummy, placebocontrolled trial. One of the main reasons is permissible to use placebo and ethically acceptable only on specific occasions (Millum and Grady, 2013). In addition, the placebo of CHMs was difficult to prepare in the same color, flavor, and taste. Third, most of trials are without calculating the formal pretrial sample size. The trials with inadequate sample sizes seem to be one risk in exaggerating intervention benefits. Finally, owing to highly variable in composition and dosage of CHMs, it is difficult to assess the efficacy of a specific CHM by performing a pooling analysis (Lewis, 1999).

\section{Implications for Practice}

The use of CHMs in the treatment of MG has increased in the past decades. However, the choice of CHMs is empirical and lacking consensus among clinic doctors. In this study, the findings demonstrated that CHM as adjuvant therapy with WCM could improve MG symptoms. The most frequently used herbs such as Astragalus membranaceus and Radix Ginseng should be considered further in the development of Chinese herbal prescription for MG. Thus, following on the treatment principle according to the high-frequency use of CHMs for MG, their treatment principles can guide to CHM treatment for MG and thus enhance the clinical effectiveness and safety. 


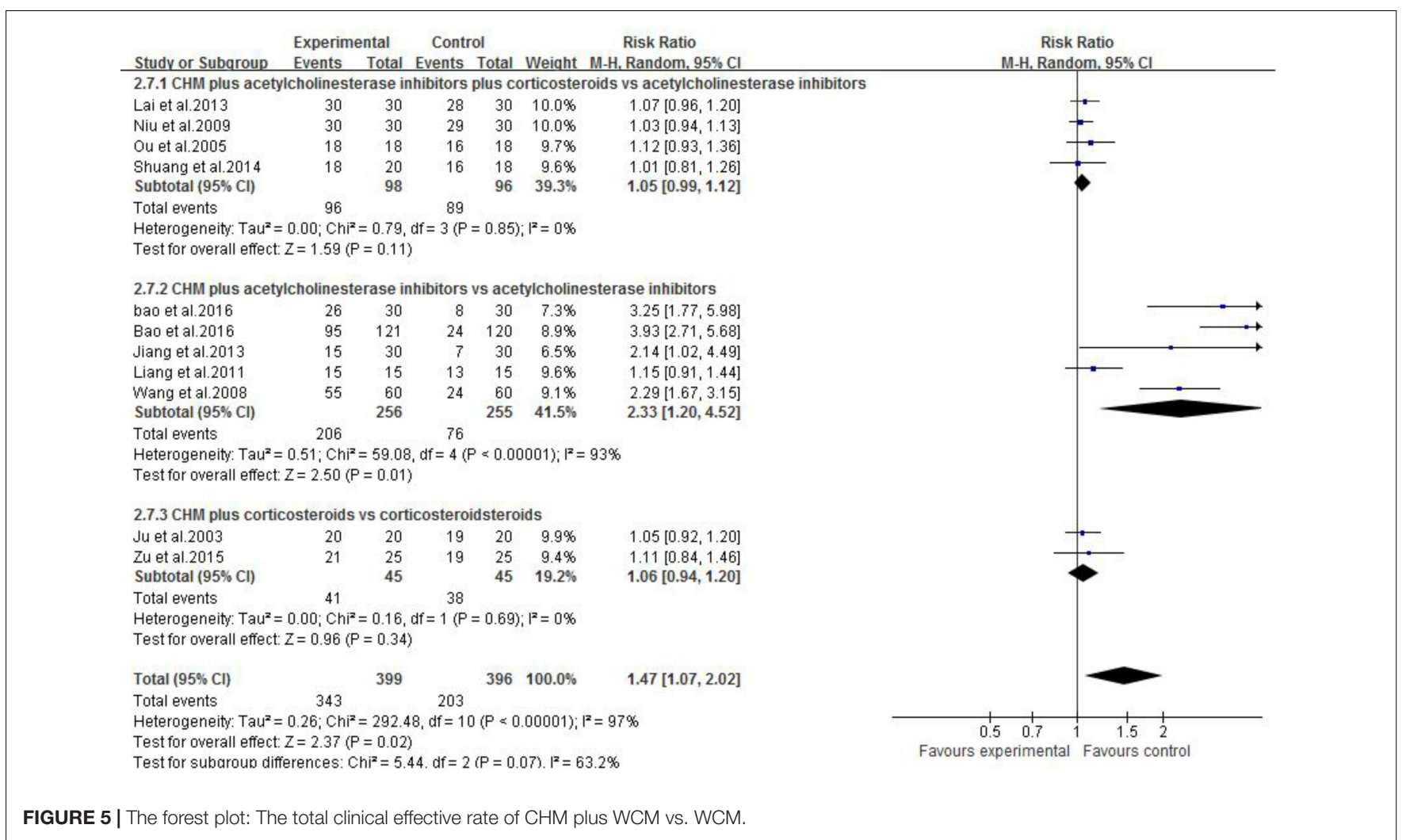

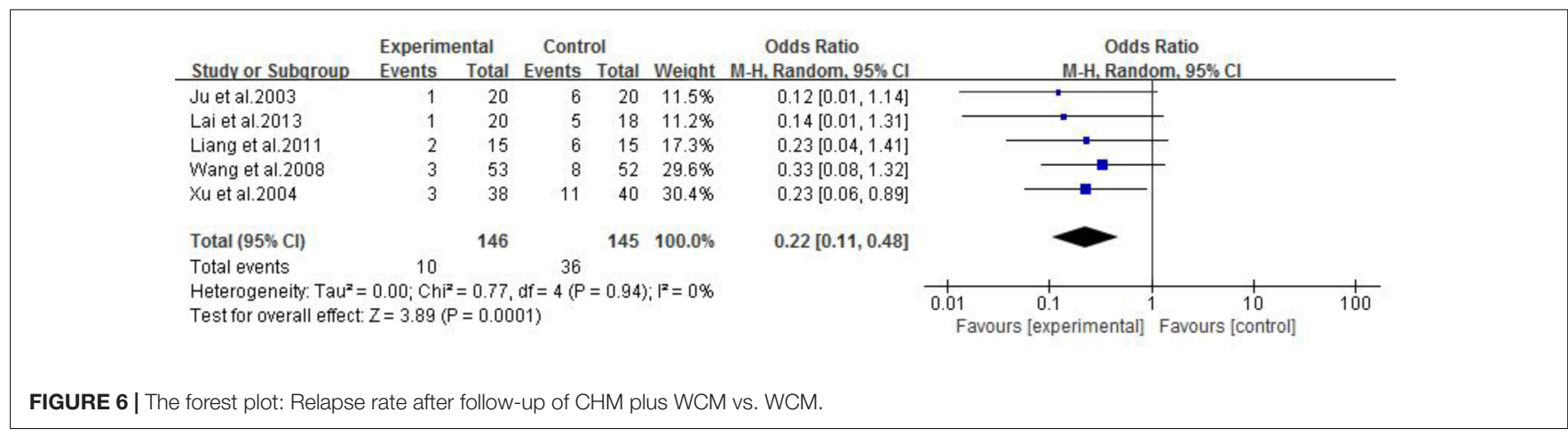

TABLE 4 | Frequently used herbs in included studies.

\begin{tabular}{|c|c|c|c|c|}
\hline Chinese name & English name & Latin name & Family & $\begin{array}{l}\text { Number of } \\
\text { studies (\%) }\end{array}$ \\
\hline Hangqi & Milkvetch root & Radix Astragali seu Hedysari/Astragalus membranaceus & Astragalus Linn. & $13(92.9)$ \\
\hline Danggui & Chinese angelica & Radix Angelicae Sinensis & Angelica L. & $12(85.7)$ \\
\hline Shengma & Largetrifoliolious bugbane rhizome & Rhizoma Cimicifugae & Cimicifuga & $8(57.1)$ \\
\hline Chaihu & Chinese thorowax root & Radix Bupleuri & Bupleurum L. & $7(50.0)$ \\
\hline Gancao & Liquorice root & Radix Glycyrrhizae & Glycyrrhiza Linn. & $5(35.7)$ \\
\hline Dangshen & Tangshen & Radix Codonopsis & Codonopsis Wall. & $4(28.6)$ \\
\hline Fangfeng & Divaricate saposhnikovia root & Radix Saposhnikoviae & Saposhnikovia Schischk & $4(28.6)$ \\
\hline Fuling & Indian bread & Poria & Wolfiporia Ryv.\&Gillbn & $4(28.6)$ \\
\hline Renshen & Ginseng & Radix Ginseng & Panax L. & $4(28.6)$ \\
\hline
\end{tabular}


TABLE 5 | Characteristics of mechanism studies.

\begin{tabular}{|c|c|c|c|c|c|c|}
\hline Included studies & $\begin{array}{l}\text { Active } \\
\text { ingredients }\end{array}$ & Herb source & $\begin{array}{l}\text { Strain, model } \\
(n / n)\end{array}$ & $\begin{array}{l}\text { Experimental } \\
\text { group }\end{array}$ & Control group & $\begin{array}{l}\text { Possible mechanisms } \\
\text { (signaling pathway) }\end{array}$ \\
\hline Qu et al., 2010 & Astragaloside & $\begin{array}{l}\text { Astragalus } \\
\text { membranaceus }\end{array}$ & $\begin{array}{l}\text { BALB/c mice, } \\
\text { Allografted } \\
\text { model }\end{array}$ & $\begin{array}{l}\text { AMI }(60 \mathrm{~g} / \mathrm{kg} \text {, i.g. ) } \\
\text { for } 14 \mathrm{~d}\end{array}$ & $\begin{array}{l}\text { NS } \\
\text { (volume-matched, } \\
\text { i.g.) for } 14 \mathrm{~d}\end{array}$ & $\begin{array}{l}\text { Up-regulate the Treg } \\
\text { ratio and promote Foxp3 } \\
\text { expression }\end{array}$ \\
\hline Jin et al., 2013 & / & $\begin{array}{l}\text { Astragalus } \\
\text { membranaceus }\end{array}$ & $\begin{array}{l}\text { SD rats, } \\
\text { asthma model } \\
(10 / 10 / 10 / 10)\end{array}$ & $\begin{array}{l}\text { AM }(2.5,5.0, \text { or } \\
10.0 \mathrm{~g} / \mathrm{kg}, \text { p.o. }) \text { for } \\
42 \mathrm{~d}\end{array}$ & $\begin{array}{l}\text { PBS } \\
\text { (volume-matched, } \\
\text { p.o.) for } 42 \mathrm{~d}\end{array}$ & $\begin{array}{l}\text { Increase population of } \\
\text { CD4+CD25+Foxp3+ } \\
\text { Treg cells and promote } \\
\text { Foxp3+ mRNA } \\
\text { expression }\end{array}$ \\
\hline Chen et al., 2014b & / & $\begin{array}{l}\text { Astragalus } \\
\text { membranaceus }\end{array}$ & $\begin{array}{l}\text { C57BL/6JNarl } \\
\text { mice, asthma } \\
\text { model }\end{array}$ & $\begin{array}{l}\text { AM (3 } \mu \mathrm{g} / \mathrm{kg}, \text { p.o. }) \\
\text { for } 8 \mathrm{~d}\end{array}$ & $\begin{array}{l}\text { NS } \\
\text { (volume-matched, } \\
\text { p.o.) for } 8 \mathrm{~d}\end{array}$ & $\begin{array}{l}\text { Increase the activity of } \\
\text { PPAR } \gamma \text { to decrease the } \\
\text { expression of Th2 } \\
\text { cytokines }\end{array}$ \\
\hline Zhao et al., 2016 & $\begin{array}{l}\text { Astragalus } \\
\text { polysaccharide }\end{array}$ & $\begin{array}{l}\text { Astragalus } \\
\text { membranaceus }\end{array}$ & $\begin{array}{l}\text { SD rats, colitis } \\
\text { model }(8 / 8)\end{array}$ & $\begin{array}{l}\text { APS }(400 \mathrm{mg} / \mathrm{kg} \text {, } \\
\text { p.o.) for } 7 \mathrm{~d}\end{array}$ & $\begin{array}{l}\text { NS } \\
\text { (volume-matched, } \\
\text { p.o.) for } 7 \mathrm{~d}\end{array}$ & $\begin{array}{l}\text { Improve the level of Treg } \\
\text { cells, regulate cytokine } \\
\text { expression }\end{array}$ \\
\hline Bae et al., 2012 & Ginsenoside Rp1 & Radix Ginseng & $\begin{array}{l}\text { C57BL/ } 6 \text { mice, } \\
\text { LPS-induced } \\
\text { inflammation } \\
\text { model }(6 / 7)\end{array}$ & $\begin{array}{l}\text { G-Rp1 (10 mg/kg, } \\
\text { p.o.) for } 7 \mathrm{~d}\end{array}$ & $\begin{array}{l}\text { PBS } \\
\text { (volume-matched, } \\
\text { i.g.) for } 7 \mathrm{~d}\end{array}$ & $\begin{array}{l}\text { Increase in Tregs is due } \\
\text { to the increase of Treg } \\
\text { survival and the } \\
\text { conversion of memory } \\
\text { type Tregs rather than } \\
\text { the generation of new } \\
\text { Tregs. }\end{array}$ \\
\hline Chen et al., 2014a & $\begin{array}{l}\text { Ginsenoside } \\
\text { metabolite } \\
\text { compound K }\end{array}$ & Radix Ginseng & $\begin{array}{l}\text { SD rats, } \\
\text { rheumatoid } \\
\text { arthritis model }\end{array}$ & $\begin{array}{l}\text { CK (10, 40, and } \\
160 \mathrm{mg} / \mathrm{kg}, \text { p.o.) } \\
\text { for } 33 \mathrm{~d}\end{array}$ & $\begin{array}{l}\text { NS } \\
\text { (volume-matched, } \\
\text { p.o.) for } 33 \mathrm{~d}\end{array}$ & $\begin{array}{l}\text { Decrease of activated } T \\
\text { cells and the increase of } \\
\text { naïve } T \text { cells and Treg }\end{array}$ \\
\hline Jhun et al., 2014 & Ginsenoside Rb1 & Radix Ginseng & $\begin{array}{l}\text { DBA } 1 \mathrm{~J} \text { mice, } \\
\text { rheumatoid } \\
\text { arthritis model }\end{array}$ & $\begin{array}{l}\text { RGE (10 mg/kg, } \\
\text { p.o.) for } 42 \mathrm{~d}\end{array}$ & $\begin{array}{l}\text { NS } \\
\text { (volume-matched, } \\
\text { p.o.) for } 42 \mathrm{~d}\end{array}$ & $\begin{array}{l}\text { Increase the number of } \\
\text { Treg cells and decrease } \\
\text { the number of } \mathrm{T} 17 \text { cells }\end{array}$ \\
\hline Lee et al., 2015 & $\begin{array}{l}\text { Ginsenoside Rg1 } \\
\text { Ginsenoside Rh1, } \\
\text { 20(S)- } \\
\text { protopanaxatriol }\end{array}$ & Radix Ginseng & $\begin{array}{l}\text { ICR mice, } \\
\text { colitis model }\end{array}$ & $\begin{array}{l}\text { Ginsenoside Rg1 } \\
\text { (20 mg/kg, p.o.) } \\
\text { Ginsenoside Rh1 } \\
\text { (20 mg/kg, p.o.) } \\
20(\mathrm{~S})- \\
\text { protopanaxatriol } \\
\text { (10 and } 20 \text { mg/kg, } \\
\text { p.o.) for } 3 \mathrm{~d}\end{array}$ & $\begin{array}{l}\text { Vehicle } \\
\text { (volume-matched, } \\
\text { p.o.) for } 3 \mathrm{~d}\end{array}$ & $\begin{array}{l}\text { Inhibit Th17 cell } \\
\text { differentiation, induced } \\
\text { to Treg cell differentiation }\end{array}$ \\
\hline Chen et al., 2016 & Ginsenoside Rb1 & Radix Ginseng & $\begin{array}{l}\text { Lewis rats, MG } \\
\text { model }(7 / 7 / 7)\end{array}$ & $\begin{array}{l}\text { G-Rb1 (2.6 and } \\
3.7 \mathrm{mg} / \mathrm{kg}, \text { p.o.) for } \\
37 \mathrm{~d}\end{array}$ & $\begin{array}{l}\text { Vehicle } \\
\text { (volume-matched, } \\
\text { p.o.) for } 37 \mathrm{~d}\end{array}$ & $\begin{array}{l}\text { Increase the percentage } \\
\text { of Treg cells, } \\
\text { up-regulated the } \\
\text { expression of IL-10 and } \\
\text { IL-4 }\end{array}$ \\
\hline Wang et al., 2009 & $\begin{array}{l}\text { Bupleurum } \\
\text { polysaccharides }\end{array}$ & Radix Bupleuri & $\begin{array}{l}\text { BALB/c mice, } \\
\text { Lupus nephritis } \\
\text { model }\end{array}$ & $\begin{array}{l}\text { BPs (30 and } \\
15 \mathrm{mg} / \mathrm{kg}, \text { p.o.) for } \\
35 \mathrm{~d}\end{array}$ & $\begin{array}{l}\text { Vehicle } \\
\text { (volume-matched, } \\
\text { p.o.) for } 35 \mathrm{~d}\end{array}$ & $\begin{array}{l}\text { Decrease autoantibodies } \\
\text { and immunoglobulin G } \\
(\mathrm{lgG})\end{array}$ \\
\hline
\end{tabular}

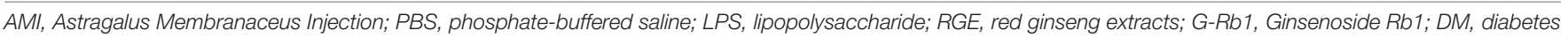
mellitus; NS, normal saline; APS, Astragalus polysaccharide; G-Rp1, Ginsenoside Rp1; CK, Ginsenoside metabolite compound K; BPS, Bupleurum polysaccharides.

\section{Implications for Research}

Some methodological weaknesses also existed in the primary trials. Thus, we recommend that CONSORT 2010 statement (Schulz et al., 2010), CONSORT for CHM Formulas (Cheng et al., 2017), and RCTs investigating CHM (Flower et al., 2012) should be used as the guidelines when the designing, registering, and reporting of further RCTs.

Naive $\mathrm{CD}^{+} \mathrm{T}$ cells can differentiate into both antiinflammatory Tregs and proinflammatory IL-17-producing $\mathrm{T}$ (Th17) cells, Th1, and Th2 (Masuda et al., 2010). Tregs play a key role in immunologic tolerance. The transcription factor FoxP3 is selectively expressed in Tregs, which is the key modulators of Tregs activation and function (Marson et al., 2007). Tregs actively mediate self-tolerance and thus control autoimmunity by suppressing the activation, proliferation, and effector function such as a cytokine production of various immune cells (Sakaguchi et al., 2008; Alahgholi-Hajibehzad et al., 2015b). Conversely, Th17 cells play a crucial role in the initiation and maintenance of autoimmune tissue injury (Schaffert et al., 2015). The disequilibrium of Th17 and Tregs is involved in the pathogenesis of various autoimmune diseases (Villegas et al., 2018). The numerical, functional, and migratory 
deficits of Tregs through cognate interactions with B cells lead to the synthesis of anti-AChR antibodies associated with MG pathogenesis (Danikowski et al., 2017). Thus, reconstitution of the Tregs disfunction or inhibition of the Th17 cells may be potential targets for MG treatment (Alahgholi-Hajibehzad et al., 2015a; Aricha et al., 2016). Cytokine networks affected the balance of Th1, Th2, Tregs, and Th17 cell subsets. IL-10 and IL4 produced by Th2 cells, serve as a protective role in MG. It was suggested that IL-10 and IL-4 were acting on the antigenpresenting cell to inhibit cytokine production by Th1 cells and also can inhibit antigen presentation of macrophages (Chen et al., 2016). In addition, IL-4 and IL-10 production increased in the presence of Treg in MG patients (Alahgholi-Hajibehzad et al., 2017).

Mechanisms of CHMs and their active components for MG are gaining attention. Notably, the included trials presented evidence of immunologic regulation effects in multiple models of autoimmune disease as follows: Astragalus membranaceus (Qu et al., 2010; Jin et al., 2013; Zhao et al., 2016), Ginsenoside Rp1, Ginsenoside Rb1, and Ginsenoside metabolite compound K (Bae et al., 2012; Chen et al., 2014a, 2016; Jhun et al., 2014) from Radix Ginseng increase number of Tregs through promoting Foxp3 expression and further an increase of endogenous Treg population, or the adaptive transfer of compatible exogenous and possibly autologous functional Tregs (Bae et al., 2012). Astragalus membranaceus can regulate a cytokine production of various immune cells (Chen et al., 2014b; Zhao et al., 2016). Ginsenoside Rb1 (Jhun et al., 2014), Ginsenoside Rg1, Ginsenoside Rh1, and 20(S)-protopanaxatriol (Lee et al., 2015) from Radix Ginseng can inhibit Th17 cell differentiation, and Ginsenoside Rb1 (Chen et al., 2016) regulates the expression of IL-10 and IL-4, BP from Radix Bupleuri reduced autoantibodies and IgG (Wang et al., 2009). HupA

\section{REFERENCES}

Alahgholi-Hajibehzad, M., Durmuş, H., Aysal, F., Gülşen-Parman, Y., Oflazer, P., Deymeer, F., et al. (2017). The effect of interleukin (IL)-21 and CD4(+) CD25(++) $\mathrm{T}$ cells on cytokine production of CD4(+) responder $\mathrm{T}$ cells in patients with myasthenia gravis. Clin. Exp. Immunol. 190, 201-207. doi: 10. $1111 /$ cei.13006

Alahgholi-Hajibehzad, M., Kasapoglu, P., Jafari, R., and Rezaei, N. (2015a). The role of T regulatory cells in immunopathogenesis of myasthenia gravis: implications for therapeutics. Exp. Rev. Clin. Immunol. 11, 859-870. doi: 10.1586/1744666X. 2015.1047345

Alahgholi-Hajibehzad, M., Oflazer, P., Aysal, F., Durmuş, H., Gülşen-Parman, Y., Marx, A., et al. (2015b). Regulatory function of CD4+CD25+ T cells inpatients with myasthenia gravis is associated with phenotypic changes and STAT5signaling: 1,25-Dihydroxyvitamin D3 modulates the suppressor activity. J. Neuroimmunol. 281, 51-60. doi: 10.1016/j.jneuroim.2015. 03.008

Aricha, R., Reuveni, D., Fuchs, S., and Souroujon, M. C. (2016). Suppression of experimental autoimmune myasthenia gravis by autologous $\mathrm{T}$ regulatory cells. J. Autoimmun. 67, 57-64. doi: 10.1016/j.jaut.2015.09.005

Bae, J., Koo, J., Kim, S., Park, T. Y., and Kim, M. Y. (2012). Ginsenoside Rp1 exerts anti-inflammatory effects via activation of dendritic cells and regulatory T Cells. J. Ginseng Res. 36, 375-382. doi: 10.5142/jgr.2012.36. 4.375 is an AChE inhibitor (Orhan, 2013). However, the specific mechanism of CHMs and their active compounds still needs clarity.

\section{CONCLUSION}

The evidence available from the present study is supported, at least to an extent, that CHMs paratherapy can be recommended for routine use for MG. Furthermore, high frequent uses of CHMs are selected to contribute to composing a herbal formula as a promising candidate for further clinical application and MG trials.

\section{AUTHOR CONTRIBUTIONS}

G-QZ contributed as the senior author and the principal investigator (PI) of this study, and refined the study. SC, M-BX, and $\mathrm{X}-\mathrm{LZ}$ wrote the first draft of the manuscript and contributed to the overall design. T-YJ and P-QR identified and reviewed the studies for eligibility, and performed the meta-analysis of the data. All authors read, critically reviewed, and approved the final manuscript.

\section{FUNDING}

This work was supported by grants from the National Natural Science Foundation of China (81573750/81473491/81173395/ H2902), the Young and Middle-Aged University Discipline Leaders of Zhejiang Province, China (2013277), and the Zhejiang Provincial Program for the Cultivation of High-level Innovative Health Talents (2015).

Bao, B. (2016). B.Clinical Observation on Myasthenia Gravis Treated by Huangqi Compound Granules. Master's thesis, Liaoning University of Traditional Chinese Medcine, Shenyang.

Bao, B., Zhang, J. S., and Qiao, W. J. (2016). Clinical observation on myasthenia gravis treated by huangqi compound granules. J. Guangxi Univ. Chin. Med. 19, $13-15$.

Barohn, R. J., McIntire, D., Herbelin, L., Wolfe, G. I., Nations, S., and Bryan, W. W. (1998). Reliability testing of the quantitative myasthenia gravis score. Ann. N. Y. Acad. Sci. 841, 769-772. doi: 10.1111/j.1749-6632.1998.tb11015.x

Benatar, M., Sanders, D. B., Burns, T. M., Cutter, G. R., Guptill, J. T., Baggi, F., et al. (2012). Recommendations for myasthenia gravis clinical trials. Muscle Nerve 45, 909-917. doi: 10.1002/mus.23330

Chen, J., Wu, H., Wang, Q., Chang, Y., Liu, K., Song, S., et al. (2014a). Ginsenoside metabolite compound $\mathrm{k}$ alleviates adjuvant-induced arthritis by suppressing $\mathrm{T}$ cell activation. Inflammation 37, 1608-1615. doi: 10.1007/s10753-0149887-0

Chen, S. M., Tsai, Y. S., Lee, S. W., Liu, Y. H., Liao, S. K., Chang, W. W., et al. (2014b). Astragalus membranaceus modulates Th1/2 immune balance and activates PPARgamma in a murine asthma model. Biochem. Cell Biol. 92, 397-405. doi: 10.1139/bcb-2014-0008

Chen, W., Meng, Q. F., Sui, J. K., Wang, Y. J., Li, X. L., Liu, S., et al. (2016). Ginsenoside Rbl: the new treatment measure of myasthenia gravis. Int. Immunopharmacol. 41, 136-143. doi: 10.1016/j.intimp.2016. 08.028 
Cheng, C. W., Wu, T. X., Shang, H. C., Li, Y. P., Altman, D. G., Moher, D., et al. (2017). CONSORT extension for Chinese herbal medicine formulas 2017: recommendations, explanation, and elaboration (traditional Chinese version). Ann. Int. Med. 167, W7-W20. doi: 10.7326/IsTranslatedFrom_M172977_1

Chinese Medical Association of Neurology Branch of neuroimmunology Group (2011). Chinese expert consensus for the diagnosis and treatment of myasthenia gravis. Chin. J. Neuro Immunol. Neurol. 18, 368-372. doi: 10.3969/j.issn.10062963.2011.05.019

Cui, L., Wang, Y., Liu, Z., Chen, H., Wang, H., Zhou, X., et al. (2015). Discovering new acetylcholinesterase inhibitors by mining the buzhongyiqi decoction recipe data. J. Chem. Inform. Model. 55, 2455-2463. doi: 10.1021/acs.jcim.5b00449

Danikowski, K. M., Jayaraman, S., and Prabhakar, B. S. (2017). Regulatory T cells in multiple sclerosis and myasthenia gravis. J. Neuroinflamm. 14, 117. doi: 10.1186/s12974-017-0892-8

Drachman, D. B., Adams, R. N., Hu, R., Jones, R. J., and Brodsky, R. A. (2008). Rebooting the immune system with high-dose cyclophosphamide for treatment of refractory myasthenia gravis. Ann. N. Y. Acad. Sci. 1132, 305-314. doi: 10.1196/annals.1405.033

Flower, A., Witt, C., Liu, J. P., Ulrich-Merzenich, G., Yu, H., and Lewith, G. (2012). Guidelines for randomised controlled trials investigating Chinese herbal medicine. J. Ethnopharmacol. 140, 550-554. doi: 10.1016/j.jep.2011.12.017

Gilhus, N. E., and Verschuuren, J. J. (2015). Myasthenia gravis: subgroup classification and therapeutic strategies. Lancet Neurol. 14, 1023-1036. doi: 10.1016/S1474-4422(15)00145-3

Gotterer, L., and Li, Y. (2016). Maintenance immunosuppression in myasthenia gravis. J. Neurol. Sci. 369, 294-302. doi: 10.1016/j.jns.2016.08.057

Higgins, J. P., and Green, S. (2011). Cochrane Handbook for Systematic Reviews of Q15 Interventions Version 5.1.0. London: The Cochrane Collaboration

Jaretzki, A., Barohn, R. B., Ernstoff, R. M., Kaminski, H. J., Keesey, J. C., Penn, A. S., et al. (2000). Myasthenia gravis: recommendations for clinical research standards. Task force of the medical scientific advisory board of the myasthenia gravis foundation of America. Neurology 55, 16-23. doi: 10.1212/WNL. 55.1 .16

Jhun, J., Lee, J., Byun, J. K., Kim, E. K., Woo, J. W., Lee, J. H., et al. (2014). Red ginseng extract ameliorates autoimmune arthritis via regulation of STAT3 pathway, Th17/Treg balance, and osteoclastogenesis in mice and human. Mediat. Inflamm. 2014:351856. doi: 10.1155/2014/351856

Jiang, C., Liu, P., Zhang, J. S., Bao, W. J., Qiu, S. B., Liang, Y., et al. (2014). Clinical study of effects of jian ji ning, a Chinese herbal medicine compound preparation, in treating patients with myasthenia gravis via the regulation of differential MicroRNAs expression in serum. Evid-Based Complement. Alternat. Med. 4:518942. doi: 10.1155/2014/518942

Jin, H., Luo, Q., Zheng, Y., Nurahmat, M., Wu, J., Li, B., et al. (2013). CD4+CD25+Foxp3+ $\mathrm{T}$ cells contribute to the antiasthmatic effects of Astragalus membranaceus extract in a rat model of asthma. Int. Immunopharmacol. 15, 42-49. doi: 10.1016/j.intimp.2012. 11.009

Ju, G. S. (2003). Randomized Controlled Trial on TanWei Capsule and Prednisone for Myasthenia Gravis. Master's thesis, Chendu University of Traditional Chinese Medcine, Chendu.

Lai, J. (2013). Clinical Study on Bupi Qiangli Compound Immunomodulatory Effect on Spleen and Kidney Deficiency Type Myasthenia Gravis. Master's thesis, Guiyang University of Traditional Chinese Medcine, Guiyang.

Lee, S. Y., Jeong, J. J., Eun, S. H., and Kim, D. H. (2015). Anti-inflammatory effects of ginsenoside Rg1 and its metabolites ginsenoside Rh1 and 20(S)protopanaxatriol in mice with TNBS-induced colitis. Eur. J. Pharmacol. 762, 333-343. doi: 10.1016/j.ejphar.2015.06.011

Lewis, J. A. (1999). Statistical principles for clinical trials (ICH E9): an introductory note on aninternational guideline. Stat. Med. 18, 1903-1942. doi: 10.1002/(SICI) 1097-0258(19990815)18:15<1903::AID-SIM188>3.0.CO;2-F

Lewis, J. A. (2003). Guidance for Industry Statistical Principles for Clinical Trials ICH Topic E9 an introductory note on an international guideline. Stat. Med. 18, 1903-1904. doi: 10.1002/(SICI)1097-0258(19990815)18:15<1903:: AID-SIM188>3.0.CO;2-F

Li, D. F. (2012). Clinical Observation and Immunoregulatory Mechanism of Myasthenia Gravis withYiqi Qushi Fang. Master's thesis, Shandong University of Traditional Chinese Medicine, Jinan.
Li, L., Xiong, W. C., and Mei, L. (2018). Neuromuscular junction formation, aging, and disorders. Annu. Rev. Physiol. 80, 159-188. doi: 10.1146/annurev-physiol022516-034255

Liang, Y. (2011). Ji Li Kang Drinking of Observe Clinical Effects Treatment of Myasthenia Graris of Spleen Deficient Type. Master's thesis, Heilongjiang Academy of Traditional Chinese Medicine, Haerbin.

Lyu, A. K., and Sun, H. Y. (2015). Chinese herbs for treatment of myasthenia gravis: a meta-analysis of randomized control trials. World Sci. Technol. Mod. Tradit. Chin. Med. Mater. Med. 17, 1492-1503. doi: 10.11842/wst.2015.07.028

Marson, A., Kretschmer, K., Frampton, G. M., Jacobsen, E. S., Polansky, J. K., MacIsaac, K. D., et al. (2007). FoxP3 occupancy and regulation of key target genes during T-cell stimulation. Nature 445, 931-935. doi: 10.1038/nature05478

Masuda, M., Matsumoto, M., Tanaka, S., Nakajima, K., Yamada, N., Ido, N., et al. (2010). Clinica limplication of peripheral CD4+CD25+ regulatory T cells and Th17 cells in myasthenia gravis patients. J. Neuroimmunol. 225, 123-131. doi: 10.1016/j.jneuroim.2010.03.016

McGrogan, A., Sneddon, S., and de Vries, C. S. (2010). The incidence of myasthenia gravis: a systematic review. Neuroepidemiology 34, 171-183. doi: 10.1159/ 000279334

Millum, J., and Grady, C. (2013). The ethics of placebo-controlled trials: methodological justifications. Contemp. Clin. Trials 36, 510-514. doi: 10.1016/ j.cct.2013.09.003

Moher, D., Liberati, A., Tetzlaff, J., and Altman, D. (2009). PRISMA Group. Preferred reporting items for systematic reviews and meta-analyses: the PRISMA statement. Ann. Intern. Med. 151, 264-269. doi: 10.7326/0003-4819151-4-200908180-00135

Niu, G. H. (2009). Clinical and Experimental Study on Huangqi Compound for Myasthenia Gravis. Dissertation, Liaoning University of Chinese Medcine, Shenyang.

Orhan, I. E. (2013). Nature: a substantial source of auspicious substances with acetylcholinesterase inhibitory action. Curr. Neuropharmacol. 11, 379-387. doi: 10.2174/1570159X11311040003

Ou, Z. S. (2005). Clinical Study on Qiangjijianliyin for Myasthenia Gravis. Master's thesis, Guangzhou University of Traditional Chinese Medcine, Guangzhou.

Qu, L. L., Su, Y. L., Li, C. X., and Hou, G. H. (2010). Astragalus membranaceus injection delayed allograft survival related with CD4+ CD25+ regulatory T cells. Transplant. Proc. 42, 3793-3797. doi: 10.1016/j.transproceed.2010. 08.032

Sakaguchi, S., Yamaguchi, T., Nomura, T., and Ono, M. (2008). Regulatory $\mathrm{T}$ cells and immune tolerance. Cell 133, 775-787. doi: 10.1016/j.cell.2008. 05.009

Sanders, D. B., Wolfe, G. I., and Narayanaswami, P. (2018). MGFA task force on MG treatment guidance. Developing treatment guidelines for myasthenia gravis. Ann. N. Y. Acad. Sci. 1412, 95-101. doi: 10.1111/nyas.13537

Sanders, D. B., Wolfe, G. I., Benatar, M., Evoli, A., Gilhus, N. E., Illa, I., et al. (2016). International consensus guidance for management of myastheniagravis: executive summary. Neurology 87, 419-425. doi: 10.1212/WNL.0000000000002790

Schaffert, H., Pelz, A., Saxena, A., Losen, M., Meisel, A., Thiel, A., et al. (2015). IL-17-producing CD4(+) T cells contribute to the loss of B-cell tolerance in experimental autoimmune myasthenia gravis. Eur. J. Immunol. 45, 1339-1347. doi: 10.1002/eji.201445064

Schulz, K. F., Altman, D. G., and Moher, D. (2010). CONSORT Group. CONSORT 2010 statement: updated guidelines for reporting parallel group randomized trials. PLoS Med. 7:e1000251. doi: 10.1371/journal.pmed.1000251

Shuang, X. P., and Tan, Z. H. (2014). Clinical study on treatment of myasthenia gravis with yiqi chushi recipe. Res. Integr. Tradit Chin. Western Med. 2, 61-64. doi: 10.3969/j.Issn.1674-4616.2014.02.002

Skeie, G. O., Apostolski, S., Evoli, A., Gilhus, N. E., Illa, I., Harms, L., et al. (2010). Guidelines for the treatment of autoimmune neuromuscular transmission disorders. Eur. J. Neurol. 17, 691-699. doi: 10.1111/j.1468-1331.2010. 03019.x

Suh, B., Goldstein, J. M., and Nowak, R. J. (2013). Clinical characteristics of refractory myasthenia gravis patients. Yale J. Biol. Med. 86, 255-260.

Villegas, J. A., Van Jw, Le, R. P., Berrihaknin, S., and Dragin, N. (2018). An imbalance between regulatory $\mathrm{t}$ cells and t helper 17 cells in acetylcholine receptor-positive myasthenia gravis patients. Ann. N. Y. Acad. Sci. 1413(Suppl. 1), 154-162. doi: $10.1111 /$ nyas.13591 
Wang, X. C., Wang, L. Y., and Li, P. (2008). Clinical observation of 60 cases of myasthenia gravis with fuyuan yiji capsule and pyridostigmine bromid. Chin. J. Practic. Int. Med. 2, 121-122. doi: 10.7504/nk2008S 2112

Wang, X. Y., Han, X., Zhang, H., and Guo, H. (1997). A clinical absolute and relative score system for myasthen ia gravis. Chin. J. Neurol. 30, 87-90. doi: 10.3760/j.issn:1006-7876.1997.02.007

Wang, Z., Li, H., Xu, H., Yue, X. L., Cheng, X. Q., Hou, W. J., et al. (2009). Beneficial effect of Bupleurum polysaccharides on autoimmune disease induced by Campylobacter jejuni in BALB/c mice. J. Ethnopharmacol. 124, 481-487. doi: 10.1016/j.jep.2009.05.013

Xu, F. Q. (2006). The Clinical Research and the Mechanism Study in Immunological Regulation of Zhongjiling Tablet in Treating Myasthenia Gravis. Dissertation, Hebei Medical University, Shijiazhuang.

Xu, Q., Chen, J. L., Ping, Y., Zhou, S. L., Huang, T., and Zhao, Z. (2004). Clinical study on treatment of myasthenia gravis with zhong Ji Ling tablets. J. Beijing. Univ. TCM 11, 4-8.

$\mathrm{Xu}, \mathrm{X} . \mathrm{H}$. (2000). Strengthening clinical and basic collaborative study on myasthenia gravis (Commentary). Chin. J. Neuroimmunol. Neurol. 7, 195-196. doi: 10.3969/j.issn.1006-2963.2000.04.001

Xu, X. H. (2003). Neuroimmunology. Beijing: Peking Union Medical University Press, 48-75.

Yang, W. T., Zheng, X. W., Chen, S., Shan, C. S., Xu, Q. Q., Zhu, J. Z., et al. (2017). Chinese herbal medicine for Alzheimer's disease: clinical evidence and possible mechanism of neurogenesis. Biochem. Pharmacol. 141, 143-155. doi: 10.1016/j.bcp.2017.07.002

Zhao, H. M., Wang, Y., Huang, X. Y., Huang, M. F., Xu, R., Yue, H. Y., et al. (2016). Astragalus polysaccharide attenuates rat experimental colitis by inducing regulatory T cells in intestinal Peyer's patches. World J. Gastroenterol. 22, 3175-3185. doi: 10.3748/wjg.v22.i11.3175

Zieda, A., Ravina, K., Glazere, I., Pelcere, L., Naudina, M. S., Liepina, L., et al. (2018). A nationwide epidemiological study of myasthenia gravis in Latvia. Eur. J. Neurol. 25, 519-526. doi: 10.1111/ene.13535

$\mathrm{Zu}$, L. H. (2015). Effective observation on treating myasthenia gravis with the Buzhong Yiqi decoction plus hormone. Clin. J. Chin. Med. 7, 76-77. doi: 10. 3969/j.issn.1674-7860.2015.28.041

Conflict of Interest Statement: The authors declare that the research was conducted in the absence of any commercial or financial relationships that could be construed as a potential conflict of interest.

Copyright (c) 2018 Chen, Xu, Zhou, Rong, Jin and Zheng. This is an open-access article distributed under the terms of the Creative Commons Attribution License (CC BY). The use, distribution or reproduction in other forums is permitted, provided the original author(s) and the copyright owner(s) are credited and that the original publication in this journal is cited, in accordance with accepted academic practice. No use, distribution or reproduction is permitted which does not comply with these terms. 